\title{
The effect of psychological violence in the workplace on health: A holistic eco-system approach
}

\author{
Authors: \\ Helen W. Meyer ${ }^{1}$ \\ Tiaan G.J.C. Kirsten ${ }^{1}$ \\ Affiliations: \\ ${ }^{1}$ Faculty of Education \\ Sciences, North-West \\ University, Potchefstroom \\ Campus, South Africa \\ Correspondence to: \\ Helen Meyer \\ Email: \\ helen.meyer@nwu.ac.za \\ Postal address: \\ Private Bag X6001, \\ Potchefstroom 2520, \\ South Africa \\ Dates: \\ Received: 27 June 2013 \\ Accepted: 14 May 2014 \\ Published: 07 Aug. 2014 \\ How to cite this article: \\ Meyer, H.W. \& Kirsten, \\ G.J.C., 2014, 'The effect of \\ psychological violence in \\ the workplace on health: \\ A holistic eco-system \\ approach', Health SA \\ Gesondheid 19(1), Art. \#757, \\ 11 pages. http://dx.doi. \\ org/10.4102/hsag.v19i1.757

\section{Copyright:} \\ (C) 2014. The Authors. \\ Licensee: AOSIS \\ OpenJournals. This work \\ is licensed under the \\ Creative Commons \\ Attribution License.
}

Read online:

Gion this QR

code with code with your smart phone or mobile device to read online.
Background: Psychological violence has emerged as a priority concern in all workplaces because of its adverse consequences on victims' health. So far, limited research has been conducted on the effect of psychological violence on the five interrelated contexts of human existence.

Objectives: This qualitative study investigated the perceived effect of psychological violence in the workplace on staff members' holistic health at a multi-campus South African Further Education and Training College. By investigating the effect of psychological violence on these five interrelated contexts, the resultant effect on holistic health might be more fully understood and applicable recommendations formulated to ameliorate the perceived effects.

Method: A qualitative, exploratory and descriptive research design was used to investigate the perceived effect of psychological violence on staff members' health. Purposeful sampling was used to select 29 participants to be interviewed individually, based on their experiences of psychological violence, as well as data saturation. The researcher analysed the data and a co-coder cross-checked the codes.

Results: The results pertaining to the perceived effects of psychological violence were positioned within the holistic eco-systemic approach as encompassing theory. Five themes were identified accordingly after data analysis, namely, psychological, biophysical, spiritual, ecological and metaphysical effects.

Conclusion: Findings revealed that psychological violence impacts adversely on all five interrelated contexts of individual health, leading to an adverse cumulative effect on staff members' holistic health and on the systems in which psychological violence occurs. Based on the findings, recommendations could be made to ameliorate the perceived adverse effect of psychological violence.

Agtergrond: Psigologiese geweld is tans besig om op die voorgrond te tree as 'n prioriteit in alle werksplekke as gevolg van die ernstige nadelige gevolge daarvan op die gesondheid van slagoffers. Tot dusver is beperkte navorsing gedoen rakende die effek van psigologiese geweld op die vyf interverwante kontekste van menslike bestaan.

Doelwitte: Hierdie kwalitatiewe studie het die waargenome effek van psigologiese geweld in die werksplek op die holistiese gesondheid van personeellede in 'n multi-kampus Verdere Onderwys en Opleiding Kollege ondersoek. Deur die effek van psigologiese geweld op hierdie vyf interverwante kontekste te ondersoek, kon die gevolglike effek op holistiese gesondheid; meer volledig verstaan word en toepaslike aanbevelings geformuleer word om die waargenome effek te verbeter.

Metode: 'n Kwalitatiewe, verkennende en beskrywende navorsingsontwerp is gebruik om die waargenome effek van psigologiese geweld op personeellede se gesondheid te ondersoek. 'n Doelgerigte steekproef is gebruik om 29 deelnemers te selekteer om indivuele onderhoude mee te voer, gebaseer op hul ervarings van psigologiese geweld, asook data versadiging. Die navorser het die data geanaliseer en 'n mede-kodeerder het die kodes kruis-kodeer.

Resultate: Die resultate rakende die waargenome effek van psigologiese geweld was geposisioneer binne die holisties eko-sistemies benadering as omvattende teorie. Vyf temas is dienoorkeenkomstig na afloop van die data-anelisering geidentifiseer naamlik psigologiese, biofisiese, spirituele, ekologiese en metafiese effekte.

Gevolgtrekking: Bevindings het aangetoon dat psigologiese geweld 'n negatiewe impak het of al vyf interverwante kontekste van individuele gesondheid wat lei tot ' $n$ negatiewe kumulatiewe effek op personeellede se holistiese gesondheid in die sisteme waar psigologiese geweld plaasvind. Aanbevelings, gebaseer op die bevindinge, kon gemaak word om die nadelige effek van psigologiese geweld te verbeter. 


\section{Introduction}

\section{Background and problem statement}

Physical violence in the workplace has received the necessary attention and recognition, but the existence of psychological violence has long been underestimated (Di Martino 2003:1). As early as 1983, the International Labour Organization (ILO) stated in their report that psychological violence should receive the same emphasis as physical violence, because of its severe consequences on health (ILO 1998:3). Psychological violence is not only a serious form of violence in the workplace, but evidence suggests that it is more prevalent than, and has consequences as severe as, physical violence (ILO 1998; Keashley 2007). For example, one in two United Kingdom (UK) employees indicated that they have been bullied at work during their working life, whilst $78 \%$ of employees who partook in a South African survey indicated that they had experienced psychological violence at least once in their careers (Ellis 2007; Work Trauma Foundation 2008a:1).

Psychological violence in the workplace refers to a cluster of behaviours which may be referred to (and are sometimes used interchangeably) as bullying, harassment, victimisation, abuse, threats, intimidation or other violent behavioural descriptors. Although a single incident can suffice, the essence of psychological violence seems to lie in its repetitive nature. It is the cumulative effect of repeated behaviours that cause the most harm to victims (Di Martino 2003:2; Hauge, Skogstad \& Einarsen 2010:427; Lutgen-Sandvik, Tracy \& Alberts 2007:840-841; Work Trauma Foundation 2008a:1; 2008b:2).

Psychological violence is characterised by negative verbal and non-verbal behaviours that may manifest in the workplace as screaming, false accusations, criticism, unprofessional conduct, negative eye contact, the withholding of information, excessive monitoring, unrealistic expectations and work overload. These behaviours usually take place in public in order to humiliate the victims. It also depends on the victim's perception as to whether negative behaviours are classified as psychological violence. A critical defining feature of psychological violence per se is the harm inflicted on the victims' health (Blase, Blase \& Du 2008:279; Ellis 2007; Hauge et al. 2010:427; Keashley 2007; Lutgen-Sandvik et al. 2007:841; Namie \& Namie 2003:32, 296; Steinman 2007:21).

Psychological violence in the workplace may emanate from superiors, colleagues of equal status, subordinates and/ or clients (Keashley 2007; Steinman 2007:22). However, superiors are more likely to be the perpetrators when it comes to psychological violence (Hauge, Skogstad \& Einarsen 2009:349). This is related to a power imbalance which is characteristic of psychological violence and refers to the victim's inability to defend him- or herself against their superior(s) (Ellis 2007). The individual's perception of psychological violence also contributes to the experienced severity of said violence. Victims who perceive psychological violence as stressful seem to suffer more severe effects, both short- and long-term. The perceived stressfulness of psychological violence and the severity thereof also seem to increase when psychological violence emanates from superiors and colleagues (Keashley 2007).

Although psychological violence transcends occupational boundaries, those employed in the health and education sectors seem to be more susceptible to experiencing psychological violence (Ellis 2007; ILO 1998). However, research on psychological violence in the South African education sector is limited and has mostly been undertaken in schools, not in Further Education and Training (FET) Colleges (Meyer 2011:6). Research should have been done in the FET sector in view of Ellis's (2007) claim that psychological violence is more likely to occur in organisations where there is a threat of redundancy, organisational change, restructuring and reform, or where job insecurity and excessive workload are experienced (Hauge et al. 2009:349). FET Colleges in South Africa are indeed in the process of transformation, reform and change. During this research, the employer of staff members at FET Colleges changed from the Department of Education to the College Council, the National Certificates Vocational (NCV) were introduced and posts were restructured, whilst the implementation of Employment Equity and affirmative action might have led to staff being left psychologically vulnerable and hence open to psychological violence (Meyer 2011:2-3; Meyer \& Kirsten 2014). The larger qualitative study that investigated the nature and perpetrators of psychological violence in the FET College confirmed that these staff members experienced psychological violence in the form of an excessive workload related to the NCV curriculum, abusive verbal and non-verbal communication, dysfunctional conduct, disengagement, unfair demands and dysfunctional management, all of which emanated mainly from their superiors at the FET College. Excessive pressure, threats and poor planning relating to the NCV curriculum emanated from the Department of Education (Meyer \& Kirsten 2014). Furthermore, in her doctoral study, Meyer (2011) found that staff experience abuse from their colleagues and students by means of dysfunctional conduct, whilst subordinates abused superiors through disengagement.

FET Colleges in South Africa provide learning and training programmes from levels 2 to 4 of the National Qualifications Framework (NQF), levels that are above general education but below higher education, as determined by the South African Qualifications Authority (SAQA) Act No. 58 of 1995 (South Africa 2005; 2006:8). Healthy and productive staff members are needed at FET Colleges in order to assist the South African youth in obtaining the necessary competencies. Staff members at the FET College consist of academic (educators) and administration (supportive) staff. Academic staff members include Lecturers, Senior Lecturers, Heads of Divisions, Campus Managers, Deans and other Senior Managers (office-based educators). Both academic and administrative staff may include management and non-management staff. Staff members who experience psychological violence from their interactions with 
superiors, colleagues and students, may not only suffer serious negative health consequences but the whole teaching learning process, including the effective training of the students at the FET College, may be affected adversely (Meyer 2011:2; Meyer \& Kirsten 2014).

FET Colleges play a vital role in South Africa with regard to addressing the national scarce-skills gap by enabling students to acquire the necessary competencies required for employment or entry into Higher Education (Parliamentary Monitoring Group 2009; South Africa 2006). Adverse effects of psychological violence in the workplace that manifest as absenteeism, an unproductive workforce, high staff turnover, unemployment and skills shortages (Ellis 2007; Hauge et al. 2010:430; Steinman 2007:28) may have a devastating effect on the FET College and exacerbate the problem of skills shortages and unemployment in the country.

National and international research has, so far, focused primarily on the effect of psychological violence on the physical, psychological or emotional well-being, work performance and social relationships of victims (Blase \& Blase 2003; Blase et al. 2008; Einarsen, Matthiesen \& Skogstad 1998; Hauge et al. 2010; Namie \& Namie 2009). Limited research has been done, however, on the effect of psychological violence on the five interrelated contexts of human existence, as described by Kirsten (2004; see also Kirsten, Van der Walt \& Viljoen 2009). This article attempts to fill this lacuna by reporting on research undertaken at a multi-campus FET College about the perceived effect of psychological violence in the workplace on the five interrelated contexts (psychological, biophysical, spiritual, ecological and metaphysical) of staff members' holistic health. It was surmised that by investigating the effect of psychological violence on these five interrelated contexts of human existence in such a College, the adverse effects of psychological violence on holistic health might be more fully understood. It was further surmised that psychological violence might have seriously negative consequences for the health of staff members, their students and the FET College in which it occurs. Hence, the research question was formulated: 'What is the perceived effect of psychological violence in the workplace on staff members' holistic health at a multi-campus South African FET College?'. The purpose of this article is to report on the findings flowing from the research that was done.

In order to reach its aim, the article is structured as follows. First of all, a conceptual-theoretical framework is outlined. This is followed by an exposition of the empirical research undertaken on the basis of that framework. Next, the findings are presented, followed by a discussion thereof against the conceptual-theoretical background. The article concludes with some recommendations.

\section{Conceptual-theoretical framework}

The effect of psychological violence in the workplace on staff members' health was considered against the backdrop of the holistic eco-systemic approach as encompassing theory. The holistic eco-systemic approach, developed by Kirsten (2004; see also Kirsten et al. 2009) and derived from the meta-approach (Jordaan \& Jordaan 1998), is embedded in systems theory. Systems theory emphasises the ecology or the science of interrelated relationships, focusing on the whole whose properties cannot be reduced to smaller parts (Capra 2012:2). Accordingly, the holistic eco-systemic approach views a human being as a whole consisting of five distinguishable but interrelated contexts (psychological, biophysical, spiritual, ecological and metaphysical) that are involved holistically in the life of a human being. As there is mutual interaction between these contexts, a change in one context will influence all other contexts (Kirsten et al. 2009). Although the effect of psychological violence on health will be described within different contexts, the impact on the system as a whole should always be borne in mind.

The following discussion on the effect of psychological violence in the workplace will be presented under the five contexts of the Holistic Eco-Systemic Model (Kirsten 2004; Kirsten et al. 2009:11).

\section{Psychological context}

This refers to experiential processes. It includes perceptual, cognitive, emotive, dispositional, self-image and/or selfconcept and subconscious processes. The effect of psychological violence in the workplace may manifest in this context as psychological health injuries serious enough to be classified by the DSM-5 (American Psychiatric Association 2013) as disorders such as post-traumatic stress disorder (PTSD) (Blase et al. 2008:277; Leymann \& Gustafsson 1996; Namie \& Namie 2009:123) and depression (Blase et al. 2008:276; De Wet 2010:1456; Hauge et al. 2010:430; Namie 2003:13). Victims may also present with negative cognitive effects, fantasies of violence against the perpetrator, suicidal ideation and substance abuse (Namie \& Namie 2003:55).

\section{Biophysical context}

This refers to biophysical processes. It includes the endocrine glands, circulatory, respiratory, gastro-intestinal, metabolic, excretory, reproductive and immune systems, amongst others. The effect of psychological violence in the workplace may manifest in this context as physical symptoms and physical diseases in victims, such as a compromised immune system, cardiovascular disease, diabetes mellitus, asthma, rheumatoid arthritis, chronic fatigue, burnout, stomach ulcers and migraines (Blase \& Blase 2003:132; Field 2002; Kivimake et al. quoted in Lutgen-Sandvik et al. 2007:838; Namie \& Namie 2009:136).

\section{Spiritual context}

The spiritual context refers to existential processes such as meaning in life, interpretation of ultimate reality or metaphysical yearning expressed as the question of what lies beyond all existence, personal belief in a deity, altered states of consciousness, inner peace and moral values related 
to one's own well-being and compassion for others. The effect of psychological violence on victims in the workplace may manifest in this context as bitterness, resentment (Blase \& Blase 2003:129; Blase et al. 2008:276), loss of hope and meaning in life, as well as suicide (Leymann 1990; Namie \& Namie 2009:312).

\section{Ecological context}

This refers to the living and non-living physical environment and can be subdivided into the economic and social contexts. It includes social community or society such as political, economic, health, educational, security and juridical contexts, amongst others, as well as the man-made environment. The effect of psychological violence in the workplace on the ecological context may be observable in the way that victims' social, work and family lives and relationships are disrupted and negatively affected. Victims may lose social support from colleagues, friends and family members and may have to forfeit their jobs in order to stop psychological violence (Blase \& Blase 2003:134-136; Namie \& Namie 2009:137). Psychological violence in the workplace may also manifest in this context as skills shortages, unemployment, an unproductive workforce and loss of income (Ellis 2007; Sheehan, Barker \& Rayner 1999; Steinman 2007:28), thus affecting economic systems and countries adversely.

\section{Metaphysical context}

The metaphysical context refers to the symbolic abstract environment. It includes the philosophical, religious, cultural and aesthetic environments, as well as the unformalised or personal views held by people regarding their realities. The effect of psychological violence in the workplace on the metaphysical context is evident in the problems victims experience regarding unformalised personal views that may manifest as sabotage and revenge (Neuman 2000). The unformalised personal views of employers may manifest as failure to support the victims (D'Cruz \& Noronha 2010).

Although the effects of psychological violence in the workplace were illustrated within different contexts, these cannot be constrained within a single context because of the interrelationships between contexts. For example, victims who experience physical ailments as a result of psychological violence in the workplace may take increased sick leave that then manifests as absenteeism and loss of productivity in organisations, resulting in skills shortages and unemployment in countries. Consequently, the adverse effects on one context simultaneously affect other contexts.

The next section reports on the empirical investigation that was launched based on the conceptual-theoretical framework outlined above.

\section{Research methods and design Aim of the empirical investigation}

The study explored and described the perceived effects of psychological violence in the workplace on staff members' health at a multi-campus FET College. The effects of psychological violence on the five contexts of these staff members' health were determined. Because of interrelationships between contexts, it was expected that the investigation would cast light on the cumulative effect on the holistic health of staff members.

\section{Research design}

A qualitative, exploratory, descriptive research design was applied in order to obtain an understanding of the effects of psychological violence on the participants' health, from their perspective (Neuman 2006:34). Qualitative research is based on the constructivist worldview that aims to understand phenomena from the participants' point of view (Creswell 2009:26).

\section{Study population and sampling}

The study population comprised 190 academic and 72 administrative staff members employed at a South African multi-campus public FET College. As academic and administrative staff members may be appointed at different levels of seniority, the study population included both management and non-management members of staff. At first, two survey instruments were distributed to the whole study population in order to determine the respondents' exposure to and nature of experienced psychological violence in the workplace and the subsequent impact thereof on their holistic health. The survey instrument included an open invitation to all respondents who had direct experience of psychological violence in the workplace to be interviewed for the qualitative part of the research. As a result of the extent of the findings, this article only reports on the qualitative part of the study, specifically the effect on victims' health.

Purposive sampling was used to select participants based on their experiences of psychological violence (Neuman 2006:222). Although 46 respondents indicated their willingness to be interviewed, interviews were held until data saturation was reached; hence the qualitative sample consisted of 29 participants. The sample comprised more academic staff members $(n=26)$ than administrative staff members $(n=3)$. It included junior, middle and senior managers $(n=13)$ from the academic group and subordinates $(n=16)$ from both the academic and administration groups.

\section{Data generation}

Individual semi-structured interviews, by appointment only, were used to collect data. The researcher conducted the interviews and kept field notes of all observations. The participants were asked how they experienced the effect of psychological violence both personally (on their health) and in a more general sense (physically, psychologically, socially, economically, spiritually, etc.) and were allowed the freedom to expand. Interviews were audio-recorded and conducted in the preferred language of the participants. Interviews lasted from 20 minutes to 2 hours and all interviews were conducted within a two-and-a-half week period during June 2009. 


\section{Data analysis}

Text from interviews and observations were transcribed and field notes were incorporated therein. Tesch's steps, as described in Creswell (2009:186), were used to analyse the data. The data set was revised several times and memos were written in the margins of transcripts to suggest possible categories (Creswell \& Plano Clark 2007:130). General themes and categories were identified and the data were then coded by dividing text into phrases, sentences and paragraphs. The codes were grouped into themes and specific quotes were cited. The Afrikaans quotes were translated freely into English to ensure that the meaning was captured.

\section{Ethical considerations}

Prior to data collection, the Chief Executive Officer of the FET College provided written approval to conduct the research and also informed each Campus Manager in writing. Ethical approval to conduct the research was obtained from the Ethics Committee of the University under whose auspices the research was conducted (reference number NWU-00097-08-S2). Interviews were held in a private pre-arranged venue which was acceptable to the participants. The participants were requested to provide informed consent and permission was granted for the audiorecording of the interviews. The participants were ensured of confidentiality; to protect anonymity, participants were numbered so that when referring to specific persons, their names were omitted. The participants were debriefed after the interviews; the researcher validated their experiences and allowed them time to talk and ask questions. The researcher also followed up on participants with suicidal ideation and suggested counselling.

\section{Trustworthiness}

The empirical research was preceded by a literature study. It was then rooted in the conceptual-theoretical framework outlined above on the effects of psychological violence and assisted in the formulation of pre-determined questions, so as to ensure credibility. Multiple data sources (a literature study, interviews and field notes) were used to triangulate the findings. To ensure trustworthiness, an independent coder was used to cross-check codes and categories (Creswell 2009:191). An external auditor (peer examiner) reviewed all the phases of the study and participants were asked whether the transcribed interviews were an acute reflection of their experiences, in order to ensure credibility (Creswell \& Plano Clark 2007:134-135).

\section{Results}

The perceived effects of psychological violence in this particular FET College can be categorised into the five main contexts of the holistic eco-systemic approach. Five themes were identified accordingly, namely, perceived psychological, biophysical, spiritual, ecological and metaphysical effects that are illustrated, along with their subthemes, in Tables 1-5. Participants ascribed most of their experiences to superiors at the FET College and the Department of Education and, to a lesser degree, to colleagues of equal status, students and subordinates (Meyer 2011:337; Meyer \& Kirsten 2014).

\section{Theme 1: Perceived psychological effects}

Twenty-one of the 29 participants experienced severe distress as a result of psychological violence. According to one manager, the stress resulted in absenteeism at work and many staff members were on incapacity leave because of stress:

'Those people who are on capacity leave, the majority of them have come from stress.' (Meyer 2011:286, Manager, male)

Participants indicated that they were depressed. Depression adversely affected other areas of their lives and resulted in an inability to commence with tasks at work. This was expressed by one of the participants as follows:

'It's probably where the depression also originated because I feel there is no hope, I do not have strength to do anything ... irrespective of how small the problem is to confront and sort out, I have ... I cannot do it.' (Meyer 2011:289, Senior lecturer, female)

Fear and anxiety were also experienced, with some participants indicating that they became anxious when going to work and were apprehensive with regard to the next psychologically-violent attack.

Feelings ranged from intense emotions and worrying to completely numbed emotions. Irritation and lethargy were indicated as some of the effects, whilst some of the participants also experienced feelings of inferiority and damaged self-esteem. Psychological violence also resulted in personality changes or acting contrary to their personalities, as well as the violation of their own moral values and ethical conduct so as to avoid negative consequences.

Participants experienced concentration problems and forgetfulness which had an adverse effect on their teaching; this was expressed as:

'I sit at work and I know I have stuff to do but it's as if I am blank, I cannot concentrate and I stand before a class and suddenly forget a subject that I have offered for seven years, that I forget what is written in the book ...' (Meyer 2011:290, Lecturer, male)

Participants also reported recurring thought patterns and brooding over their adverse experiences, resulting in an inability to 'switch off' after hours and spend time with their families. This affected their sleeping patterns and was expressed as:

'During the night, I think about these things and it causes me to brood over these things' (Meyer 2011:569, Lecturer, male); and

'[I]t's like your brain doesn't switch off, you are busy thinking the whole time.' (Meyer 2011:569, Senior lecturer, male)

Some participants tried to repress or 'block out' their thoughts about psychological violence, but then they dreamt of these experiences: 
'At a stage I decided when I get home then I may not even think about work ... about how it affected me, so I switch off completely or I try, but now I dream every evening about it so I don't really switch off.' (Meyer 2011:332, Senior lecturer, female)

Victims also reported an increased use of substances such as alcohol and cigarettes as a way of coping with psychological violence.

Some female participants indicated that they cried continuously, even whilst at home:

'I was in tears every day at home, I couldn't handle it; every day I cried when I got up when I must go to work.' (Meyer 2011:288, Senior lecturer, female)

Another cried so much during the interview that she had to stop talking at times. Participants felt frustrated because they could not do anything to stop the psychological violence. This resulted in anger and thoughts of violence against the perpetrators to such an extent that victims wanted to do serious physical harm, as was evidenced in the wording they used, such as 'beating someone up' or 'slapping the perpetrator across the ear' (Meyer 2011:294, Manager, male). One participant expressed this as:

'I just didn't want to fight. I wanna [sic] make sure one of us is going to the mortuary, but I wanted to make a serious thing that day, I was, I was very angry, I was very angry.' (Meyer 2011, Lecturer, female)

It is disturbing that four participants reported that they had suicidal thoughts on a regular basis:

'What I can say to you is that very often I thought of suicide especially at that stage when things really were bad with my family [cries] because I felt that I lost everything, I lost my position and my career. I am busy losing my husband, I am busy losing my children, so what's the use?' (Meyer 2011:292, Lecturer, female)

Thus, it became evident that psychological violence at the FET College not only affected the victim adversely, resulting in job loss, but also had adverse effects that extended to their family lives and their relationships.

\section{Theme 2: Perceived biophysical effects}

Twelve participants were constantly tired to the point of exhaustion resulting from psychological violence, as is evident from the use of the following words and phrases: 'exhausted', 'I am finished', 'tired already', 'I am tired, tired, tired, tired until death', 'tired all the times' and 'dead tired'. Participants experienced severe and constant headaches and migraines. Some had to use pain tablets on a daily basis, received weekly injections and visited the doctor regularly because of the severity and continuous nature of their headaches, whilst one migraine sufferer indicated:

'I have been hospitalised for a week due to migraines.' (Meyer 2011:307, Lecturer, female)

Eleven participants experienced chronic sleeplessness as a result of psychological violence. Whereas some woke up
TABLE 1: Perceived psychological effects of psychological violence at the Further Education and Training College.

\begin{tabular}{llc}
\hline Theme & Perceived psychological effects & $\mathbf{2 1}$ \\
\hline Subthemes & Distress & 11 \\
& Recurring thought patterns (brooding) & 11 \\
Frustration & 10 \\
Anger & 7 \\
Personality changes, acting contrary to & \\
personality and becoming a 'changed' person & 6 \\
Crying & 6 \\
Depression & 4 \\
Concentration problems & 4 \\
Fear and anxiety & 4 \\
Forgetfulness & 4 \\
Irritation & 4 \\
Suicidal thoughts & 3 \\
Consuming more alcohol & 3 \\
Feelings of inferiority and damaged self esteem & 3 \\
Lethargy & 3 \\
Numbed emotions (anhedonia) & 3 \\
Thoughts of violence & 3 \\
Intense emotion & 3 \\
Feeling worried & 3 \\
Having to violate own moral values and ethical & 3 \\
conduct & 3 \\
Repressing thoughts about negative experiences & 3 \\
Wanting to retaliate (retribution) & 3 \\
Becoming aggressive & 3 \\
\hline
\end{tabular}

during the night or in the early hours of the morning, others could not sleep at all. One participant reported that she could not sleep in spite of sleep medication:

'So I remain awake the whole night, I do not sleep, I suffer from insomnia and even if they have treated me with severe medication for sleeping, I cannot sleep.' (Meyer 2011:300, Senior lecturer, female)

Recurring thoughts related to psychological violence also impacted on participants' sleep patterns:

' $[D]$ uring the night I woke up, I think about the workplace, I cannot sleep during the night.' (Meyer 2011:300, Administration clerk, female)

Conversely, some participants indicated that they slept excessively, from one to three days at a time, as a result of the effects of psychological violence.

Bodily pains and painful, tensed shoulders were reported, as well as stomach problems including nausea and vomiting, stomach aches and cramps, sensitivity, diarrhoea, spastic colon and chronic stomach ulcer, overeating and weight gain and lack of appetite. One participant mentioned that she vomited in the morning at the thought of coming to work.

Some participants experienced severe and continuous heart palpitations as a result of psychological violence. Participants attributed serious cardiovascular diseases, such as hypertension, angina and other such complaints, to their psychological violence experiences: 
'I have in this past time picked up heart problems that I never had previously and I had to go for heart tests and there were two arteries that are closed that in the future may have to have bypasses.' (Meyer 2011:306, Senior lecturer, female)

One participant also indicated how the psychological effects of the violence contributed to her hypertension:

'All my life long I have never had health problems, I never had it, but here I have blood pressure because I am always the hell in, I am always furious, I am always frustrated, I cannot go through a day without feeling frustrated and irritated and yes it takes its toll. I have now got high blood pressure.' (Meyer 2011:305, Senior lecturer, female)

A re-appearance and worsening of existing diseases was reported, including asthma, auto-immune disease and diabetes, whilst arthritis was reported as being a new medical condition directly attributed to psychological violence. Participants had to use a combination of medication such as anti-depressants, tranquilisers, sleep medication, muscle relaxants, headache and pain tablets to the point of addiction, as well as homeopathic remedies, vitamins and supplements as a means of addressing their physical and psychological ailments that resulted from the psychological violence they were experiencing.

\section{Theme 3: Perceived spiritual effects}

Nine participants felt that everything had become too much to handle and that they could not cope anymore because of the psychological violence. Participants used phrases such as: 'I want to collapse and give up' (Meyer 2011:597, Lecturer, male); 'I cannot cope anymore, come to a stage that you crack' (Meyer 2011:597, Senior lecturer, female); 'you just cannot continue anymore, you cannot handle it anymore' (Meyer 2011:309, Senior lecturer, female). Some participants had a negative outlook on life with no positive expectations about the future. They claimed that psychological violence had a negative effect on their relationship with God and they had started to question the role of God in their negative experiences. Participants also experienced unfairness and felt a lack of control over their situation. As a result of the psychological violence, participants experienced feelings of dejection, desperation, bitterness and resentment. One participant verbalised the seriousness of the cumulative effect of psychological violence as follows:

'The effect is too broad, a person destroys people's lives if you are so unfair ... because you actually commit murder, you commit psychological murder; for me it was psychological murder.' (Meyer 2011:314, Lecturer, female)

\section{Theme 4: Perceived ecological effects}

Most of the participants indicated that psychological violence at work had a simultaneous negative effect on their relationships with their families. The stress experienced at work, as well as the tiredness, feelings of frustration, dejection, anger, negativity, crying and recurrent thoughts about psychological violence, were also experienced at home and caused distance between the participants and their family members. One participant mentioned:
TABLE 2: Perceived biophysical effects of psychological violence at the Further Education and Training College.

\begin{tabular}{llc}
\hline Theme & Perceived bio-physical effects & N $\mathbf{2 9}$ \\
\hline Subthemes & Tiredness and exhaustion & 12 \\
& Headaches & 12 \\
& Insomnia & 11 \\
& Having to use medication and food supplements & 9 \\
& Bodily pains & 5 \\
& Painful and tensed shoulders & 5 \\
Worsening of existing diseases; new medical conditions & 5 \\
appearing & \\
Heart palpitations & 4 \\
Stomach aches and cramps, stomach sensitivity, & 4 \\
diarrhoea, chronic stomach ulcer and spastic colon & \\
High blood pressure (hypertension) & 3 \\
Overeating, weight gain and a lack of appetite & 3 \\
Teeth grinding (teeth gnashing) & 3 \\
Heart cramps and heart disease & 2 \\
Migraine headaches & 2 \\
Nausea and vomiting & 2 \\
Excessive sleep & 2 \\
\hline
\end{tabular}

TABLE 3: Perceived spiritual effects of psychological violence at the Further Education and Training College.

\begin{tabular}{llc}
\hline Theme & Perceived spiritual effects & $N \mathbf{2 9}$ \\
\hline Subthemes & $\begin{array}{l}\text { Feeling that everything has become too much to handle } \\
\text { and that one cannot cope anymore }\end{array}$ & 9 \\
& $\begin{array}{l}\text { Negative outlook on life } \\
\text { Negative personal views held by non-management }\end{array}$ & 6 \\
employees regarding their realities & 5 \\
No positive expectations about the future & 4 \\
Perceptions that management cannot be trusted & 4 \\
Questioning role of God in bad experiences & 3 \\
Affecting relationship with God negatively & 2 \\
Bitterness and resentment & 2 \\
Dejection and desperation & 2 \\
Lack of control over own situation & 2 \\
Unfairness & 2 \\
\hline
\end{tabular}

'You take what happens at work, you take it home, your relationship with those at home, your husband, your children ... often when I am so irritated when I leave here, I want to bite every one's head off and no one knows what's happening to me.' (Meyer 2011:315, Senior lecturer, female)

Psychological violence also resulted in marital conflict, which in turn impacted negatively on the participants' children. The participants' relationships with their colleagues and students were affected adversely; they lost trust in others, withdrew and reported that they were unable to focus or provide quality instruction:

'It does affect the way you deliver, the way you relate with your students.' (Meyer 2011:317, Lecturer, female)

Participants dreaded coming to work and experienced diminished creativity and initiative, job insecurity and uncertainty, no job satisfaction, demoralisation and lack of motivation, as is evident in their use of words such as 'sluggish', 'demotivated' and 'demoralised'. Some participants also reported that they became less productive as a result of the violence; some took increased sick leave and were often absent. One manager expressed the collateral effect of psychological violence on the economy and the College as follows: 
'If you take the number of absenteeism that we've got extremely high in three-month period - we've had a R170-odd thousand rand loss to a company in three months; [this] is high although some of those people are on [in]capacity leave. They're booked off by their psychologists, their psychiatrists; one woman has cracked completely - she will never return to work because of, I believe, bullying tactics.' (Meyer 2011:322, Manager, male)

Participants also reported a high staff turnover as many staff members have resigned because of the psychological violence, whilst remaining staff members were actively seeking alternative employment.

\section{Theme 5: Perceived metaphysical effects}

Metaphysical effects reported by participants included the fact that they experienced racism as a consequence of the new political dispensation; they also experienced the implementation of affirmative action as being negative and discriminatory, feeling that minority groups were subjected to psychological violence. One of them expressed this in the following terms: '[t]he discrimination against me was based on race' (Meyer 2011:621, Lecturer, female). They also indicated that they worked in an environment of 'survival of the fittest' and had fears regarding retribution should they speak out. Management participants also held negative views regarding the toxicity of the work environment. This was expressed as follows:

'The staff members that we manage are undergoing serious stress that would really need a specialist to come and assist us, otherwise we are going to lose staff members due to illness, to death at some point; it can also cause death - or sometimes, due to sudden resignation ... [sic]' (Meyer 2011:327, Manager, male).

\section{Discussion}

It became evident from the findings that psychological violence at the FET College impacted negatively on all five contexts of the staff members' holistic health. In line with the holistic eco-systemic approach, it transpired that the adverse effect on one context had a simultaneous adverse effect on other contexts, resulting in a 'cumulative' (Field 2002) effect on the holistic health of victims.

\section{Psychological effects}

Previous research alluded to psychological violence as a constant stressor (Hauge et al. 2010), that may result in psychological health injuries serious enough to be classified by the DSM-5 (American Psychiatric Association 2013) as disorders (Meyer 2011:428), such as depression and PTSD (Blase \& Blase 2003:124; Namie \& Namie 2009:123). Many participants in this research experienced distress; this concurs with related findings that stress is one of the most significant symptoms of psychological violence (De Wet 2010:1456; Ellis 2007; Hauge et al. 2010:1). Participants also experienced depression that is in line with previous research which states that psychological violence often results in depression (Blase \& Blase 2003:124; Blase et al.
TABLE 4: Perceived ecological effects of psychological violence at the Further Education and Training College.

\begin{tabular}{|c|c|c|}
\hline Theme & Perceived ecological effects & $N=29$ \\
\hline \multirow{6}{*}{$\begin{array}{l}\text { Subtheme: } \\
\text { Perceived } \\
\text { social effects }\end{array}$} & Affecting relationships with family negatively & 19 \\
\hline & Withdrawing from other people & 6 \\
\hline & $\begin{array}{l}\text { Affecting relationships with students and quality of } \\
\text { instruction negatively }\end{array}$ & 5 \\
\hline & $\begin{array}{l}\text { Affecting social relationships with colleagues and others } \\
\text { negatively }\end{array}$ & 5 \\
\hline & Having no time for social life due to work overload & 3 \\
\hline & Losing trust in other people & 3 \\
\hline \multirow{8}{*}{$\begin{array}{l}\text { Subtheme: } \\
\text { Perceived } \\
\text { economic } \\
\text { effects }\end{array}$} & Dreading coming to work & 11 \\
\hline & Demoralisation and lack of motivation & 10 \\
\hline & No job security and experiencing feelings of uncertainty & 9 \\
\hline & $\begin{array}{l}\text { Seeking other employment and resigning (high staff } \\
\text { turnover) }\end{array}$ & 9 \\
\hline & Diminished creativity and initiative & 4 \\
\hline & Being less productive & 3 \\
\hline & $\begin{array}{l}\text { Taking more sick leave and experiencing increased } \\
\text { absenteeism }\end{array}$ & 3 \\
\hline & Experiencing no job satisfaction & 2 \\
\hline
\end{tabular}

TABLE 5: Perceived metaphysical effects of psychological violence at the Further Education and Training College.

\begin{tabular}{llc}
\hline Theme & Perceived ecological effects & $N=\mathbf{2 9}$ \\
\hline Subthemes & $\begin{array}{l}\text { Experiencing the implementation of affirmative action } \\
\text { negatively }\end{array}$ & 4 \\
& $\begin{array}{l}\text { Working in an environment of 'survival of the fittest' } \\
\text { Experiencing racism as a consequence of the new } \\
\text { political dispensation } \\
\begin{array}{l}\text { Minority groups are being subjected to psychological } \\
\text { violence }\end{array}\end{array}$ & 3 \\
$\begin{array}{l}\text { Negative personal views held by management regarding } \\
\text { the toxicity of the work environment } \\
\text { Having fears of retribution if one speaks out }\end{array}$ & 3 \\
\hline
\end{tabular}

2008:276; De Wet 2010:1456; Hauge et al. 2010:430; Namie 2003). Symptoms related to depression such as anger (Blase \& Blase 2003:120), hopelessness, an inability to commence with tasks, lethargy and feeling down (as recorded in the diagnostic criteria of the DSM-5 [American Psychiatric Association 2013]) were also reported, substantiating participants' claims of depression. The participants also reported fear and anxiety as being perceived effects of psychological violence (Blase \& Blase 2003:4; Blase et al. 2008:276-277; Hauge et al. 2010:430; Namie 2003:17).

Participants also experienced typical symptoms related to PTSD, namely, recurring thought patterns, obsessive and intrusive thoughts and difficulty concentrating. Leymann and Gustafsson (1996) and Namie and Namie (2009) also reported that PTSD was an effect of psychological violence. Concentration problems as an effect of psychological violence were also reported by Blase et al. (2008:276) and Namie (2003). In this research, an inability to concentrate as reported could be symptomatic of both depression and PTSD.

In line with previous research, participants in this research also experienced feelings of violence toward their perpetrators (Namie 2003). The finding on suicidal thoughts also concur with the literature and previous research amongst victims of psychological violence (Neuman 2000; Workplace Bullying Institute 2000:9). This finding sheds some light on the experienced harm of psychological 
violence at the FET College and should be considered in a serious light given that suicidal thoughts are precursors to the act of suicide. What became evident from this finding is that psychological violence in the workplace is a 'crushing experience' (Steinman 2007:27), that it is not constrained to one context of a victim's life and often results in job loss and/ or in collateral effects in the victim's relationships and family life to such an extent that the victim wants to commit suicide.

\section{Biophysical effects}

The perceived biophysical effects of psychological violence on staff members' health in the FET College included serious physical symptoms and physical diseases. Many participants indicated tiredness to the point of exhaustion. The seriousness thereof was reflected in the wording they used in addition to severe and constant headaches, chronic sleeplessness and teeth grinding. Other studies similarly alluded to tiredness and exhaustion (Blase \& Blase 2003:131; Blase et al. 2008:276; Ellis 2007; Lewis 2004:296), headaches (Blase \& Blase 2003:131; De Wet 2010:8; Namie 2003), insomnia (Blase \& Blase 2003:276; Blase et al. 2008:276; De Wet 2010:1456; Keashley 2007; Namie \& Namie 2009:135) and teeth grinding (Blase et al. 2008:277; Namie 2003) amongst victims of psychological violence.

Insomnia, also reported here, is a biophysical symptom of both PTSD and depression, whilst excessive sleep - so far only reported by victims in this research - is also a symptom of depression. This may suggest that those victims who took part in this research and experienced a number of related symptoms to PTSD and/or depression may have suffered from these conditions. Sleeplessness may result from stress as stress increases body temperature and skin resistance, narrows blood vessels and causes more bodily movements which make sleeping uncomfortable and different (Hafen et al. 1996:15).

Consistent with previous research, the findings in this research also suggest that psychological violence may be associated with serious cardiovascular diseases including hypertension (Blase \& Blase 2003:132; Namie \& Namie 2009:36), angina and other heart conditions (Kivimaki et al. quoted by Lutgen-Sandvik et al. 2007:838, 855; Namie \& Namie 2009). It might be noteworthy that one participant who was diagnosed with hypertension mentioned that she was always angry. Hafen et al. (1996:8) reported in this regard that there is a link between hypertension and anger, or expressed anger and resultant guilt, or the inability to protest against an unjustifiable attack. The same participant also mentioned that she repressed feelings because one has to act according to a certain code in the workplace. According to Hafen et al. (1996), the severe emotional stress such as was experienced by victims in this research may lead to disturbances in heart rhythm and trigger an angina attack. Severe and continuous heart palpitations (Blase \& Blase 2003:132; Blase et al. 2008:277) might also be related to panic attacks, fear and anxiety resulting from psychological violence. As both the fear and anxiety were reported here are psychological effects, this may provide some explanation for the cardiovascular effects reported.

The findings also corroborate previous research stating that victims of psychological violence experience stomach problems, overeating, weight gain or weight loss (Blase et al. 2008:277; Namie \& Namie 2009:136), vomiting and nausea (Blase \& Blase 2003:132; Keashley 2007) and bodily pains (Blase et al. 2008:277), although the occurrence of painful and tensed shoulders was a new finding. The worsening of existing diseases and new medical conditions appearing also concur with previous studies conducted in the education sector (Blase \& Blase 2003:133). Similarly, diabetes, asthma (Blase \& Blase 2003:132; Blase et al. 2008:276) and arthritis (Namie \& Namie 2009) were also reported previously, but in different contexts.

\section{Spiritual effects}

Psychological violence at the FET College also violated aspects of staff members' health in the spiritual context. Corresponding with other studies, participants also experienced bitterness, resentment (Blase \& Blase 2003:120; Blase et al.2008:276), rejection (Lewis 2004:296), lack of control (Keashley 2007) and unfairness (Namie \& Namie 2009:141). However, these phenomena were not indicated previously as spiritual findings as was done in this research. Staff members also indicated that everything had become too much to handle that refers to an inability to cope (Leymann 1990). Other new findings also emerged here, including negative views held by non-management employees and perceptions that management cannot be trusted, a negative outlook and no positive expectations about the future, questioning the role of God in bad experiences and the negative effect on victims' relationships with God, all of which reflect the adverse effect of psychological violence in the spiritual context. It can thus be argued that the perceived spiritual effects of psychological violence in this particular FET College may be associated with the experience of existential crisis in the lives of the participants.

\section{Ecological effects}

It is evident from the findings that psychological violence at this FET College cannot be constrained to staff members' biophysical, psychological and spiritual health but that it also extends to their families, spouses, children and even students, who become the unseen victims thereof (Blase et al. 2008:276-277; Namie \& Namie 2009). Similar to the findings of Blase and Blase (2003:135) and Blase et al. (2008:276), participants were unable to compartmentalise their experiences of psychological violence, a state of affairs that had an adverse effect on participants' relationships with colleagues at work and led to a loss of trust in other people.

The effects of psychological violence manifested clearly at the FET College and impacted negatively thereupon. Adverse effects reported previously, namely, low morale (Blase et al. 2008:276), high staff turnover (Blase \& Blase 2003:13; 
Keashley 2007;), diminished creativity and initiative (Blase \& Blase 2003:96; Blase et al. 2008:276; De Wet 2010:1457), increased sick leave and absenteeism (Blase et al. 2008:277; Namie \& Namie 2003:57) were confirmed in this study under the heading 'ecological context'. The adverse effects of psychological violence in the workplace as reported here also provide some concrete evidence regarding the financial loss for companies. Job insecurity and uncertainty, reported in this article, might be attributed to the changes currently experienced in the South African FET sector.

\section{Metaphysical effects}

Staff members from minority groups who experienced the implementation of affirmative action as psychological violence and as racism as a consequence of the new political dispensation, were a new finding, although previously alluded to in the American context by Namie (2007:9), whilst Steinman (2007:113) similarly found that minority groups in South Africa are at increased risk of experiencing psychological violence.

Negative views held by management regarding the toxicity of the work environment confirmed the psychological violence experienced by non-management level participants. Participants also mentioned that they worked in an environment of 'survival of the fittest', which is typical of an abusive workplace or hostile organisational culture where psychological violence is likely to thrive (Namie \& Namie 2009:22).

The findings indicated that the adverse effect of psychological violence at this FET College is not constrained to victimised staff members' individual health, as is evident from the reported psychological, biophysical and spiritual effects, but that it also extended to their colleagues, students and teaching-learning process, the FET College and the country, as is evident from the perceived ecological and metaphysical effects. This research sheds light on the adverse effects of psychological violence on the five interrelated contexts of staff members' health within the FET College and also seems to point to the collateral effect of psychological violence in the workplace on victims' health in all contexts of their existence and systems. It may also broaden our understanding of the problem in our efforts at assisting victims of psychological violence in the workplace.

\section{Recommendations}

The Department of Education, superiors and staff members at FET Colleges should be informed about the findings of this study through presentations and publications such as this article. Awareness may make perpetrators realise that they are engaging in psychological violence and make them aware of the adverse effect thereof on staff members' health. Awareness is necessary with regard to bringing about attitude changes to minimise the prevalence of psychological violence at the FET College, thereby also ameliorating the adverse effects on staff members' health (Meyer 2011:362).
A 360-degree feedback system (DFS) (Mamatoglu 2008:431, 438) could be introduced at the FET College whereby subordinates assess superiors and one another anonymously. Regular feedback from the 360 (DFS) is anticipated to improve communication (Mamatoglu 2008:431, 438) between staff, thereby also ameliorating the adverse effect in the ecological context (Meyer 2011:373-375).

A work-life balance policy could be introduced at the FET College to ensure that staff members have time to recover from stress and to ameliorate the biophysical effects, namely, tiredness and exhaustion, that also impact on staff members' family members in the ecological context. A work-life balance policy could also be effective with regard to reducing absenteeism and sick leave (Allen et al.; Brough et al. quoted in Brough \& O’Driscoll 2010:291; Meyer 2011:379).

Peer group support is essential (Lewis 2004:295). Support from one's colleagues might minimise the experienced severity of psychological violence and discourage perpetrators from targeting victims. Superiors might also alter their negative behaviour if they are made to realise that the large majority of staff members disapprove thereof. Support from other staff members and superiors might prevent and reduce the experienced severity of psychological violence in the ecological context

Counselling, psychotherapy and medical treatment are recommended in order to ameliorate the serious adverse effects of psychological violence on the psychological, biophysical and spiritual contexts of staff members. Staff members who experience depression, anxiety and substance abuse may also benefit from support groups such as SADAG (South African Depression and Anxiety Group) and AA (Alcoholics Anonymous).

From a holistic eco-systemic approach, the recommendations to ameliorate psychological violence in a single context are expected to have a positive cumulative effect in other contexts.

It emerged from the qualitative interviews that participants experienced symptoms of depression and PTSD; this could be researched by making use of valid diagnostic tools.

\section{Limitations}

Not all the participants who indicated their interest to be interviewed could be interviewed. An intervention programme could have benefited all the staff members who took part, including those who wished to be interviewed based on their experiences of psychological violence.

\section{Conclusion}

It became evident from the findings that psychological violence in the workplace impacted adversely on all contexts of staff members' health at the multi-campus FET College. Because of interrelationships between contexts, 
psychological violence in the workplace is not only costly to staff members at the FET College, but also to their families, colleagues, students, the whole teaching-learning process and the economic system of the country. Preventative and supportive strategies should be introduced at the FET College so as to ameliorate the adverse effects of psychological violence in the workplace on staff members' holistic health. Based on the holistic eco-systemic approach, the strategies to prevent and ameliorate the effects of psychological violence in one context are expected to have a positive cumulative effect in other contexts.

\section{Acknowledgements}

This research was undertaken for the requirements of a Doctorate in Educational Psychology.

\section{Competing interests}

The authors declare that they have no financial or personal relationship(s) which may have inappropriately influenced them in writing this article.

\section{Authors' contributions}

H.M. (North-West University) conducted the research as part of a Doctorate in Educational Psychology and wrote the manuscript. T.K. (North-West University) was the study leader and provided feedback on and approved the article.

\section{References}

American Psychiatric Association, 2013, DSM-5: Diagnostic and statistical manual of mental disorders, 5th edn., American Psychiatric Association, Arlington, VA.

Blase, J. \& Blase, J., 2003, Breaking the silence: Overcoming the problem of principal mistreatment of teachers, Sage Publications Ltd., California.

Blase, J., Blase, J. \& Du, F., 2008, 'The mistreated teacher: A national study', Journal of Educational Administration 46(3), 263-301. http://dx.doi. org/10.1108/09578230810869257

Brough, P. \& O'Driscoll, M.P., 2010, 'Organizational interventions for balancing work and home demands: an overview', Work \& Stress 24(3), 280-297. http://dx.doi.or $\mathrm{g} / 10.1080 / 02678373.2010 .506808$

Capra, F., 2012, The new facts of life, viewed 12 June 2014, from http://www. ecoliteracy.org/essays/new-facts-life

Creswell, J.W., 2009, Research design: Qualitative, quantitative, and mixed methods approaches, 3rd edn., Sage Publications Ltd., California.

Creswell, J.W. \& Plano Clark, V.L., 2007, Designing and conducting mixed methods research, Sage Publications Ltd., California.

D'Cruz, P. \& Noronha, E., 2010, 'Protecting my interests: HRM and targets' coping with workplace bullying', The Qualitative Report 15(3), 507-534.

De Wet, C., 2010, 'The reasons for and the impact of principal-on-teacher bullying on the victims' private and professional lives', Teaching and Teacher Education 26(7) 1450-1459. http://dx.doi.org/10.1016/j.tate.2010.05.005

Di Martino, V., 2003, Workplace violence in the health sector: Relationship between work stress and workplace violence in the health sector, Joint Programme on Workplace Violence in the Health Sector, Geneva.

Einarsen, S., Matthiesen, S. \& Skogstad, A., 1998, 'Bullying at work: Bullying, burnout and well-being among assistant nurses', Journal of Occupational Health and Safety: Australia and New Zealand 14(6), 563-568.

Ellis, A., 2007, Workplace bullying, Ruskin College, Oxford, UK.

Field, T., 2002, 'Staffroom bullying', viewed 19 June 2014, from http://www.jaredstory. com/staff_bully.html

Hafen, B.Q., Karren, K.J., Frandsen, K.J. \& Smith, N.L., 1996, Mind/body health - the effects of attitudes, emotions, relationships, Allyn \& Bacon, Massachusetts.
Hauge, L.J., Skogstad, A. \& Einarsen, S., 2009, 'Individual and situational predictors of workplace bullying: why do perpetrators engage in the bullying of others?' Work \& Stress 23(4), 349-358. http://dx.doi.org/10.1080/02678370903395568

Hauge, L.J., Skogstad, A. \& Einarsen, S., 2010, 'The relative impact of workplace bullying as a social stressor at work', Scandinavian Journal of Psychology 51(5), 426-433.

International Labour Organization, 1998, Violence on the job - a global problem, viewed 12 June 2014, from http://www.ilo.org/global/about-the-ilo/newsroom/ news/WCMS 007970/lang--en/index.htm

Jordaan, W. \& Jordaan, J., 1998, People in context, 3rd edn., Heinemann, Johannesburg.

Keashley, L., 2007, The research of Loraleigh Keashley, Ph.D. - interpersonal and systemic aspects of emotional abuse at work, Wayne State University, Detroit, MI.

Kirsten, G.J.C., 2004, 'Out of Africa: exploratory thoughts in weaving the beginnings of a wellness counselling and therapy model', poster presented at the 2nd European Conference on Positive Psychology, Verbania Pallanza, Italy, 5-8 July.

Kirsten, G.J.C., Van der Walt, H.J.L. \& Viljoen, C.T., 2009, 'Health, well-being and wellness: an anthropological eco-systemic approach', Health SA Gesondheid 14(1), Art. \#407, 7 pages.

Leymann, H., 1990, 'Mobbing and psychological terror at workplaces', European Journal of Work and Organizational Psychology 5(2), 165-184. http://dx.doi org/10.1080/13594329608414853

Leymann, H. \& Gustaffson, A., 1996, 'Mobbing at work and the development of post-traumatic stress disorders', European Journal of Work and Organizational Psychology 5(2), 251-275. http://dx.doi.org/10.1080/13594329608414858

Lewis, D., 2004, 'Bullying at work: the impact of shame among university and college lecturers', British Journal of Guidance \& Counselling 32(3), 281-299. http://dx.doi. org/10.1080/03069880410001723521

Lutgen-Sandvik, P., Tracy, S.J. \& Alberts, J.K., 2007, 'Burned by bullying in the American workplace: prevalence, perception, degree and impact', Journal of Management Studies 44(6), 837-862. http://dx.doi.org/10.1111/j.1467-6486.2007.00715.x

Mamatoglu, N.M., 2008, 'Effects on organizational context (culture and climate) from implementing a 360-degree feedback system: the case of Arcelik' European from implementing a 360-degree feedback system: the case of Arcelik' European
Journal of Work and Organizational Psychology, 17(4), 426-449. http://dx.doi. Journal of Work and Organization
org/10.1080/13594320802281094

Meyer, H.W., 2011, 'The nature and impact of psychological violence on staff members' health in FET colleges: strategies for prevention and support', PhD thesis in Educational Psychology, North West University, Potchefstroom.

Meyer, H.W. \& Kirsten, G.J.C., 2014, 'Psychological violence at a multi-campus Further Education and Training College', South African Journal of Higher Education, accepted for publication.

Namie, G., 2003, 2003 report on abusive workplaces, viewed 12 June 2014, from http://www.workplacebullying.org/multi/pdf/N-N-2003C.pdf

Namie, G., 2007, The US Workplace Bullying Survey September, 2007, viewed 18 June 2014, from http://workplacebullying.org/multi/pdf/WBIsurvey2007.pdf

Namie, G. \& Namie, R., 2003, The bully at work: what you can do to stop the hurt and reclaim your dignity on the job, Sourcebooks, Inc., Naperville, IL.

Namie, G. \& Namie, R., 2009, The bully at work: what you can do to stop the hurt and reclaim your dignity on the job, 2nd edn., Sourcebooks, Inc., Naperville, IL.

Neuman, J.H., 2000, Injustice, stress and bullying can be expensive!, paper presented at the first US-based international conference on workplace bullying, Oakland, CA

Neuman, W.L., 2006, Social research methods: qualitative and quantitative approaches, 6th edn., Pearson Education/Allyn and Bacon, Boston, MA.

Parliamentary Monitoring Group, 2009, Further Education \& Training (FET) colleges: government interventions, viewed 12 June 2014, from http://www.pmg.org.za/
report/20090204-department-education-government-interventions-furtherreport/20090204-c

Sheehan, M., Barker, M. \& Rayner, C., 1999, 'Applying strategies for dealing with workplace bullying', International Journal of Manpower 20(1/2), 50-57. http:// workplace bullying', International Journal
dx.doi.org/10.1108/01437729910268632

South Africa, 1995, South African Qualifications Authority Act 58 of 1995, Government Printers, Pretoria.

South Africa, 2006, Further Education and Training Colleges Act 16 of 2006 Government Printers, Pretoria.

Steinman, S.M., 2007, Don't take shit from hyenas at work: Reclaim your dignity - be hyena-wise!, The People Bottomline, Roodepoort, South Africa.

Workplace Bullying Institute, 2000, U.S. hostile workplace survey 2000, viewed 12 June 2014, from http://www.workplacebullying.org/multi/pdf/N-N-2000.pdf

Work Trauma Foundation, 2008a, Workplace bullying in South Africa, viewed 07 February 2008, from http://www.worktrauma.org/survive_bully/bullying_in_ sa.htm [link no longer valid]

Work Trauma Foundation, 2008b, Definitions adopted by the Work Trauma Foundation viewed 07 February 2008, from http://www.worktrauma.org/change/definitions. $\mathrm{htm}$ [link no longer valid] 